\title{
Saliva leukocytes rather than saliva epithelial cells represent the main source of DNA
}

\section{Leucocitele salivare şi nu celulele epiteliale din salivă reprezintă principala sursă de ADN}

\author{
Corina Maria Cianga ${ }^{1,3}$, Ion Antohe ${ }^{2,4}$, Mihaela Zlei ${ }^{1,5}$, Daniela Constantinescu ${ }^{1,3}$, \\ Petru Cianga ${ }^{1,3^{*}}$
}

1. Department of Immunology, University of Medicine and Pharmacy "Grigore T. Popa” Iasi;

2. Department of Haematology, University of Medicine and Pharmacy "Grigore T. Popa" Iasi;

3. Laboratory of Immunology and Genetics "St. Spiridon” Hospital, Iasi;

4. Department of Haematology, Regional Institute of Oncology, Iasi;

5. Laboratory of Medical Investigations, Regional Institute of Oncology, Iasi

\begin{abstract}
Introduction. Several alternative methods to peripheral blood DNA extraction have been implemented so far. Saliva seems to represent a very advantageous type of sample, easy to harvest and able to generate DNA yields comparable to those extracted from blood mononuclear cells.

Material and methods. 8 patients suspected of ankylosing spondylitis, 9 patients with various hematological malignancies, displaying post-chemotherapy leucopenia and 30 healthy volunteers were included in our study. DNA was extracted with various commercially available kits and used for HLA typing either by PCR amplification, or by PCR followed by hybridization.

Results. Our data regarding HLA typing support already published results regarding the good DNA quality that allows its use in various molecular biology techniques. However, when attempting to use saliva from immunosuppressed patients for DNA extraction we have generated very low yields, comparable again with the ones obtained from peripheral blood. Flow cytometry and immunocytochemistry investigations confirmed the low number of leukocytes present in the saliva of these patients, while the number of epithelial cells was virtually unchanged.

Conclusions. The main source of saliva DNA seems to be represented by leukocytes present in this fuid and not by the epithelial cells. Under these circumstances, for immunosuppressed patients saliva cannot represent an alternative to blood when attempting DNA extraction.
\end{abstract}

Keywords: Saliva, DNA, leukocytes, epithelial cells

*Corresponding author: Petru Cianga, University of Medicine and Pharmacy “Grigore T. Popa” Iasi, Romania, e-mail: petrucianga@hotmail.com 


\section{Rezumat}

Introducere. Există mai multe metode de extracţie a ADN-ului implementate ca alternativă la sângele periferic. Saliva pare să fie un tip de probă avantajos, uşor de recoltat şi cu posibilitatea de a genera ADN comparabil cu acela extras din celulele mononucleare ale sângele periferic.

Material şi metodă. Am inclus în studiul nostru 8 pacienţi suspecţi de spondilită anchilopoetică, 9 pacienţi cu diverse afecţiuni hematologice maligne, prezentând leucopenie post-chimioterapie şi 30 voluntari sănătoşi. ADNul a fost extras cu variate kit-uri comerciale disponibile şi utilizat pentru tiparea HLA prin amplificare PCR, urmată de hibridizare.

Rezultate. Rezultatele noastre referitoare la tiparea HLA sunt în concordanţă cu date publicate deja, referitoare la calitatea bună a ADN-ului extras din salivă, ceea ce permite utilizarea acestuia în diverse tehnici de biologie moleculară. Totuşi, extracţia ADN-ului din saliva de la pacienţi imunodeprimaţi a avut un randament scăzut, comparabil cu cel din sângele periferic. Investigarea prin citometrie în flux şi imunocitochimie a confirmat numărul mic de leucocite în saliva acestor pacienţi, în timp ce numărul celulelor epiteliale a fost similar cu cel al loturilor de comparatie.

Concluzii. Principala sursă de ADN din salivă pare să fie reprezentată de leucocite şi nu de celulele epiteliale. În aceste circumstanţe, la pacienţii imunodeprimați, saliva nu este o alternativă superioară sângelui pentru extracţia de $A D N$.

Cuvinte cheie: Saliva, ADN, leucocite, celule epiteliale

Received: $16^{\text {th }}$ November 2015; Accepted: $16^{\text {th }}$ February 2016; Published: $8^{\text {th }}$ March 2016

\section{Introduction}

For genetic analyses human DNA can be extracted from a variety of sources. Peripheral blood DNA extraction seems to be the method of choice for most laboratories, a procedure for which there are also clear guidelines regarding the blood drawing and storage [1]. However, alternative DNA sources have been considered and correspondent extraction methods have been implemented and standardized. While for cadaveric donors the spleen represents an important option and tumor biopsies might be critical in particular circumstances, for living patients or healthy individuals, collection methods like mouthwash, cytobrush, mucosal swabs and even saliva collection tend to become increasingly used. Each such method presents advantages and disadvantages.

While whole blood generates, in most cases, a sufficient amount of good quality DNA, harvesting peripheral blood is an invasive method which requires a phlebotomist, presents an important discomfort, a risk of infection or hemorrhage. Furthermore, the stability of blood samples is limited at room temperature (RT) and blood tubes require $4^{\circ} \mathrm{C}$ storage conditions and special packaging conditions if they are to be shipped [2].

Brushes or swabs generate good DNA yields [3], but they require careful harvesting, by well trained medical personnel, and the extraction can pose technical difficulties, as supplementary steps to transfer the sample from the brush or swab into solution are mandatory.

The mouthwash collection method, even if very simple, requires a solution with a relatively high content of alcohol, which can be ill-tolerated by many persons, especially children [4]. Hence, it is considered that for children, swabs and cytobrushes are more advantageous for DNA extraction [5-7].

On the other hand, saliva sampling is a very comfortable method, easily accepted by patients, however still regarded with reluctance by many physicians for a number of potential problems that might be considered. As the number of cells present in this type of sample is projected by many to be lower than in a regular blood sam- 
ple, a major concern is regarding the amount of DNA that can be extracted. However, there are an increasing number of studies that have shown that high yields of DNA can be extracted from saliva [8-10]. Another important issue is about the purity of the saliva DNA, as biological contaminants, especially bacteria, but also viruses and fungi are clearly present, even in the fluids of healthy individuals. As a consequence, concerns were raised regarding the purity and overestimation of DNA concentrations [8], but again, many studies demonstrated the high quality of the extracted DNA [9-12] that can be used for RT-PCR, PCR-RFLP [13], and even Sanger genotyping [8] or for New Generation Sequencing (NGS) [11].

Both DNA quantity and quality are critical for any type of gene analysis and this is why whole blood DNA extraction is still preferred and imposed by accrediting procedures for most current molecular biology investigations, HLA typing, and DNA sequencing. On the other hand, should large studies, based on an important number of volunteers, are to be considered, the compliance of participants represents an important issue for the success of the study and, when faced with a non-invasive method, the participants are much easier to convince [14].

Commercial kits are made available for saliva harvesting. They consist of a vial where the donors are required to spit, the optimal saliva volume being indicated by the manufacturer. A solution that contains chemicals able to prevent DNA degradation and bacterial growth is then added and the two liquids are mixed. Manufacturers claim that such samples can be stored at RT for at least one year and still be able to generate a reasonable amount of undegraded DNA $[15,16]$. By consequence, these features make saliva sample collection an important option for DNA extraction due to the simplicity of the sampling, which allows self harvesting and stability, which further reflects in storing conditions and shipping.

Several studies attempting DNA extraction from saliva using various commercial harvesting kits, some performed on very large cohorts, have already been published $[11,12,17,18]$, confirming that this biological sample is a reliable one for extracting human DNA.

However, as not the fluid but the mixture of cells to be found in saliva represents the proper source of DNA, the question which further arose was regarding the type of cells that constitute themselves as the main source. Due to the rather large number of epithelial cells, around $4.3 \mathrm{x}$ $10^{5} / \mathrm{ml}[19]$ and due to the continuous turn over that enables the replacement of the surface layer at approximately every 3 hours [19] one would expect that these particular cells will be able to provide a sufficient amount of DNA [13].

This was our assumption as well when we have decided to approach saliva for DNA extraction as an alternative to blood, having in mind primarily the immunosuppressed patients, for which the regular blood DNA yields are often insufficient with respect mostly to PCR amplifications.

To the best of our knowledge, this study brings evidence for the first time that the saliva epithelial cells do not represent the main DNA source but rather the cells originating from the blood stream and crossing into the oral cavity are the ones targeted by the various commercially available DNA extraction kits.

\section{Materials and methods}

\section{Patients and healthy individuals}

Blood and saliva were harvested from 8 patients suspected of ankylosing spondylitis, for which HLA-B27 genotyping was recommended, and from 9 patients with various hematological malignancies, displaying post-chemotherapy leucopenia. 
Also, a group of 30 healthy volunteers were included in this study, for which only saliva was harvested.

Saliva was harvested and used after an informed consent was obtained.

\section{Blood harvesting}

As we intended to use the extracted DNA in several types of PCR, the blood was harvested using vacutainers with either EDTA or citrate based anti-clotting agents, but not with heparin.

\section{Saliva harvesting}

The saliva was harvested using the commercial Oragene DNA device from DNA Genotek (Canada). The harvesting kit contains a stabilizing liquid which is mixed with a certain volume of saliva, indicated by the manufacturer. Once the liquids are mixed, the samples can be stored at room temperature (RT) before DNA extraction.

\section{DNA extraction}

The purification of the genomic DNA from saliva was initially attempted using a demo prepIT ${ }^{\mathrm{TM}}$ CD2 Genomic DNA MiniPrep kit, recommended by the same manufacturer (DNA Genotek, Cana$\mathrm{da}$ ), according to the provided protocol. The kit is based on columns endowed with a matrix able to retain the precipitated DNA. After gently shaking the saliva harvested as described above, the tubes were incubated for 1.5 hours at $50^{\circ} \mathrm{C}$ in a dry bath. Then, $500 \mu 1$ of saliva were mixed with $350 \mu \mathrm{l}$ of PT buffer and vortexed at top speed for $15 \mathrm{sec}$. The entire mix was transferred into the MiniPrep Column and centrifuged at 8,000 rpm for $1 \mathrm{~min}$. After discarding the flow through, the column was washed with $500 \mu$ l of Wash Buffer 1 (60\% ethanol) for $1 \mathrm{~min}$ at 8,000 rpm and then twice with $700 \mu \mathrm{l}$ Wash buffer 2 (70\% ethanol) at 12,000 rpm for $1 \mathrm{~min}$. The DNA was eluted by centrifuging the column for $1 \mathrm{~min}$ at $12,000 \mathrm{rpm}$ with $100 \mu \mathrm{l}$ Elution Buffer pre-warmed at $65^{\circ} \mathrm{C}$.

The DNA was then extracted using an adsorbtion columns based "mini" Life Technology commercial kit (Invitrogen, Life Technologies, Carlsbad, CA, USA), dedicated to small blood volumes, usually between 200 and $300 \mu$ l. The protocol we have used, similar to the one described above, was the same as for peripheral blood, according to the manufacturer's indications. Thus $200 \mu \mathrm{l}$ of sample (saliva and stabilizer mix, or blood) were incubated with $20 \mu$ of RNase and $20 \mu \mathrm{l}$ of proteinase $\mathrm{K}$ for $2 \mathrm{~min}$. at RT. Then, $200 \mu$ of proteinase $\mathrm{K}$ buffer were added and the mix was thoroughly vortexed. After 10 minutes incubation at $55^{\circ} \mathrm{C}$, the DNA was precipitated with $200 \mu \mathrm{l}$ of $100 \%$ ethanol and introduced in a Life Technology column that was centrifuged at 10,000 rpm for $1 \mathrm{~min}$. Two washes were performed at 10,000 rpm for $1 \mathrm{~min}$, and 13,000 rpm for $3 \mathrm{~min}$, using two different ethanol based buffers. The elution was performed by centrifugation at 13,000 rpm for $1 \mathrm{~min}$, with 200 $\mu 1$ elution buffer.

\section{DNA concentration measurement}

DNA concentration was quantified with a Beckman Coulter DU800 spectrophotometer, in a $100 \mu$ cuvette, at a 1/10 dilution in water. The absorbtion was measured simultaneously at 260 $\mathrm{nm}$ and at $280 \mathrm{~nm}$ as well, in order to determine the potential protein contamination.

\section{PCR}

An HLA-SSP (Sequence Specific Primers) approach was considered for this test. We have used a commercial kit dedicated to HLA-B27 typing, based on a single pair of primers (BAG Health Care Gmbh, Lich, Germany). The alleles amplified by these primers are, according to the manufacturer, HLA-B2701-2717, 2719-2721, 2724-2728, 2730-2732, and 2734-2745. The size of the control band is of 1070 base pairs (bp), while the amplicon should have a size of $420 / 85$ bp. The reaction is set for a $10 \mu \mathrm{l}$ volume, and the following components were mixed: $1 \mu \mathrm{l}$ of DNA (20-40 ng/ $\mu \mathrm{l}), 1 \mu \mathrm{l}$ of PCR buffer (that includes $\mathrm{MgCl}$ ), $0.1 \mu \mathrm{l}$ of Histo-Taq polymerase 
(BAG Health Care Gmbh, Lich, Germany) and 8 $\mu \mathrm{l}$ of molecular grade $\mathrm{H}_{2} \mathrm{O}$ (Sigma Aldrich, Germany). The mix was then added to the tube containing the dehydrated primers and pipetted up and down until the primers were completely solubilized. The amplification set-up is as follows:

\begin{tabular}{|c|c|c|c|c|}
\hline 1 & 1 cycle & $94^{\circ} \mathrm{C}$ & $5 \min$ & Denaturing \\
\hline 2 & 5 cycles & $\begin{array}{l}96^{0} \mathrm{C} \\
68^{\circ} \mathrm{C}\end{array}$ & $\begin{array}{l}20 \mathrm{sec} \\
60 \mathrm{sec}\end{array}$ & $\begin{array}{l}\text { Denaturing } \\
\text { Annealing and } \\
\text { extension }\end{array}$ \\
\hline 3 & 10 cycles & $\begin{array}{l}96^{0} \mathrm{C} \\
64^{0} \mathrm{C} \\
72^{\circ} \mathrm{C} \\
\end{array}$ & $\begin{array}{l}20 \mathrm{sec} \\
50 \mathrm{sec} \\
45 \mathrm{sec}\end{array}$ & $\begin{array}{l}\text { Denaturing } \\
\text { Annealing } \\
\text { Extension }\end{array}$ \\
\hline 4 & 15 cycles & $\begin{array}{l}96^{0} \mathrm{C} \\
61^{\circ} \mathrm{C} \\
72^{\circ} \mathrm{C}\end{array}$ & $\begin{array}{l}20 \mathrm{sec} \\
50 \mathrm{sec} \\
45 \mathrm{sec}\end{array}$ & $\begin{array}{l}\text { Denaturing } \\
\text { Annealing } \\
\text { Extension }\end{array}$ \\
\hline 5 & 1 cycle & $72^{\circ} \mathrm{C}$ & $5 \mathrm{~min}$ & Final extension \\
\hline
\end{tabular}

\section{PCR and hybridization}

The simultaneous genotyping of HLA-B27 and of the cytochrome P450 2D6 genes was performed by PCR multiplex amplification followed by a reverse hybridization assay, using a HLA-B*27 and CYP2D6*4 commercial kit (GenID Gmbh, Strassberg, Germany). The PCR amplification was set in a $25 \mu \mathrm{l}$ reaction volume using the following amplification conditions:

\begin{tabular}{|c|c|c|c|c|}
\hline 1 & 1 cycle & $95^{\circ} \mathrm{C}$ & $5 \mathrm{~min}$ & Denaturing \\
\hline 2 & 10 cycles & $\begin{array}{l}95^{\circ} \mathrm{C} \\
68^{\circ} \mathrm{C}\end{array}$ & $\begin{array}{l}30 \mathrm{sec} \\
120 \mathrm{sec}\end{array}$ & $\begin{array}{l}\text { Denaturing } \\
\text { Annealing and } \\
\text { extension }\end{array}$ \\
\hline 3 & 22 cycles & $\begin{array}{l}95^{\circ} \mathrm{C} \\
55^{0} \mathrm{C} \\
72^{\circ} \mathrm{C}\end{array}$ & $\begin{array}{l}10 \mathrm{sec} \\
30 \mathrm{sec} \\
30 \mathrm{sec}\end{array}$ & $\begin{array}{l}\text { Denaturing } \\
\text { Annealing } \\
\text { Extension }\end{array}$ \\
\hline 5 & 1 cycle & $72^{\circ} \mathrm{C}$ & $8 \mathrm{~min}$ & Final extension \\
\hline
\end{tabular}

The amplification was followed by hybridization of oligonucleotides fixed on nitrocellulose strips. $20 \mu$ of the PCR mix were denatured using an equal volume of denaturing solution provided by the kit, for $5 \mathrm{~min}$ at room temperature. Then, each strip was covered by $1 \mathrm{ml}$ of hy- bridization solution, previously heated at $47^{\circ} \mathrm{C}$. The hybridization was performed at $47^{\circ} \mathrm{C}$, for 30 min, in a water bath with a shaker tray. After the removal of the hybridization buffer, the strips were washed twice for $1 \mathrm{~min}$ and once for 15 min at $47^{\circ} \mathrm{C}$ with the stringent wash buffer provided by the kit. Once the stringent wash buffer was removed, the strips were then twice washed with a 1:5 diluted rinse buffer, for $1 \mathrm{~min}$ at RT. After the rinse buffer removal, the strips were incubated for $30 \mathrm{~min}$ at RT with $1 \mathrm{ml}$ of 1:100 dilution of streptavidin-enzyme conjugate. After 3 rinses performed at RT for $1 \mathrm{~min}$, the strips were covered with $1 \mathrm{ml}$ of substrate and the color reaction was monitored. As the bands started to become visible, the reaction was stopped by removing the substrate buffer as soon as possible and by rinsing the strips with distilled water.

\section{May-Grünwald Giemsa staining}

Saliva smears were stained for 5 min at RT with a May Grünwald (Sigma Aldrich, Germany) solution (previously diluted with an equal volume of water), then immersed for $30 \mathrm{~min}$ in a 1/10 dilution Giemsa solution, after which they were washed with distilled water and dried.

\section{Immunocytochemistry}

Identification of the various cells present in saliva was initially performed by immunocytochemistry. The epithelial cells were labeled with monoclonal anti-cytokeratin antibody (MNF16, Dako, Denmark) [20] while the leukocytes were identified with the monoclonal anti-CD45 antibody (Dako, Denmark)]. Neutrophils were labeled with monoclonal anti-CXCR1 (IL-8 RA) and anti-CXCR2 (IL-8 RB) antibodies (BD Biosciences Pharmingen, USA) [21,22].

The cells from saliva samples were attached by centrifugation at $300 \mathrm{~g}$ on glass slides and fixed for 15 minutes in $100 \%$ ethanol, at room temperature (RT). 
The slides were incubated first with $3 \%$ $\mathrm{H}_{2} \mathrm{O}_{2}, 5 \mathrm{~min}$, RT, to quench the endogenous peroxidases, washed in distilled water, $5 \mathrm{~min}$ and phosphate-buffered saline (PBS), 5 min. Then, the cells were incubated with $2 \%$ fetal bovine serum in RPMI 1640 (Sigma Aldrich, Germany), for $30 \mathrm{~min}$, RT, to block non-specific binding sites, followed by washing in PBS, for $5 \mathrm{~min}$, RT. The incubation with the primary antibodies was performed at the concentrations recommended by the manufacturers, at $4^{\circ} \mathrm{C}$, overnight, followed by two washings in PBS, 5 min, RT. The binding of all primary mouse anti-human antibodies was detected with the EnVision Dual Link System-HRP kit (Dako, Denmark). The slides were initially incubated with the secondary antibodies conjugated with an HRP labeled polymer for $30 \mathrm{~min}$, washed in PBS, $5 \mathrm{~min}$, RT, then incubated with $\mathrm{DAB} /$ hydrogen peroxide, 15-20 min, RT. The slides were counterstained with Mayer's hematoxylin (Dako, Denmark). Secondary antibodies and Streptavidin-HRP were used as negative controls.

\section{Flow cytometry}

The saliva samples were transferred into $5 \mathrm{ml}$ tubes and washed with at least $4.5 \mathrm{ml}$ PBS by centrifugation at RT, 500g, $5 \mathrm{~min}$. After discarding the supernatant, the pellet was vortexed and resuspended in $100 \mu$ isotone fluid. The cells were labeled with $2 \mu \mathrm{l}$ anti-CD45 antibody PeCy5, clone MEM-28, Exbio, CZ) for $30 \mathrm{~min}$, at RT, and washed with $2 \mathrm{ml}$ isotone fluid. After removing the supernatant, the pellet was resuspended and subjected to analysis with a BD FACSAria III flow cytometer (FACSDiva software).

\section{Results}

For 4 patients with ankylosing spondylitis the saliva was collected with the Oragene harvesting system and the DNA yields obtained using a demo prepIT ${ }^{\mathrm{TM}} \mathrm{CD} 2$ Genomic DNA MiniPrep kit from the same manufacturer (Genotek, Canada) are presented in Table 1.

Table 1. DNA concentrations obtained with the Oragene DNA saliva harvesting system and the prepIT $^{\mathrm{TM}}$ CD2 Genomic DNA MiniPrep kit, as compared with DNA yields obtained from peripheral blood with the Life Technology DNA extraction kit.

\begin{tabular}{lll}
\hline Patient initials & & \\
\hline B G & $\begin{array}{l}260 \mathrm{~nm} / 280 \mathrm{~nm} \\
\text { ratio }\end{array}$ & $\begin{array}{l}\text { Concentration } \\
\mu \mathrm{g} / \mathrm{ml}\end{array}$ \\
\hline blood & 1.9669 & 23.05 \\
\hline saliva & 1.9239 & 51.53 \\
\hline C M & & \\
\hline blood & 2.0027 & 25.37 \\
\hline saliva & 1.6984 & 13.77 \\
\hline L V & & 19.13 \\
\hline blood & 1.8372 & 30.24 \\
\hline saliva & 1.8865 & \\
\hline S D & & 42.49 \\
\hline blood & 1.9264 & 51.20 \\
\hline saliva & 1.8068 & 200
\end{tabular}

DNA average concentration extracted from $200 \mu$ of blood: $27.51 \mu \mathrm{g} / \mathrm{ml}$

DNA average concentration extracted from $500 \mu 1$ of saliva: $36.68 \mu \mathrm{g} / \mathrm{ml}$

In a similar manner, for the other 4 patients with ankylosing spondylitis saliva was collected with a demo Genotek saliva harvesting system and extracted with the Life Technology DNA extraction kit. The yields are presented in Table 2. The patient CM was not compliant and despite our indications, the saliva volume that he supplied was three times more than required, hence, due to the sample dilution, a low concentration of DNA was obtained.

For this group of patients, when comparing the blood and the saliva DNA extraction from a volume of sample of $200 \mu \mathrm{l}$, despite the differences evidenced by the measurements presented above, we have noticed that the average 
Table 2. DNA concentrations obtained with Genotek saliva harvesting kit as compared with DNA yields obtained from peripheral blood with the Life Technology DNA extraction kit.

\begin{tabular}{lll}
\hline Patient initials & & \\
\hline B G & Ratio $260 / 280$ & Concentration $\mu \mathrm{g} / \mathrm{ml}$ \\
\hline blood & 1.9669 & 23.057 \\
\hline S5 & 1.8672 & 25.96 \\
\hline C M & Ratio $260 / 280$ & Concentration $\mu \mathrm{g} / \mathrm{ml}$ \\
\hline blood & 2.0027 & 25.3724 \\
\hline S5 & 1.6649 & 8.1686 \\
\hline L V & Ratio $260 / 280$ & Concentration $\mu \mathrm{g} / \mathrm{ml}$ \\
\hline blood & 1.8372 & 19.1307 \\
\hline S5 & 1.9295 & 35.8471 \\
\hline S D & Ratio $260 / 280$ & Concentration $\mu \mathrm{g} / \mathrm{ml}$ \\
\hline blood & 1.9264 & 42.4929 \\
\hline S5 & 1.9514 & 40.5 \\
\hline
\end{tabular}

DNA average concentration extracted from $200 \mu 1$ of blood: $27.51 \mu \mathrm{g} / \mathrm{ml}$

DNA average concentration extracted from $200 \mu 1$ of saliva: $27.61 \mu \mathrm{g} / \mathrm{ml}$

yields are remarkably similar: $27.51 \mu \mathrm{g} / \mathrm{ml}$ for blood, versus $27.61 \mu \mathrm{g} / \mathrm{ml}$ for saliva, even considering an outlier, as is the case for patient CM.

Under these circumstances, we were encouraged to pursue DNA extraction from saliva samples and we have opted for the second set-up, given the fact that the Life Technology extraction kit is currently used in our laboratory. The yields obtained from $200 \mu \mathrm{l}$ of saliva (diluted in equal volumes with the stabilizing agent) harvested from 30 healthy donors are presented in Table 3.

The mean DNA value obtained in this setup was $30.96 \mu \mathrm{g} / \mathrm{ml}$, which is slightly higher than the amount of DNA that we currently manage to extract from peripheral blood samples (roughly around $28 \mu \mathrm{g} / \mathrm{ml}$ ). However, it should be noted that this extraction method, unlike DNA extraction from peripheral blood, may generate in some cases important yield differ-
Table 3. DNA concentrations obtained with the Genotek saliva harvesting system and the Life Technology "mini" DNA extraction kit.

\begin{tabular}{|c|c|c|}
\hline $\begin{array}{l}\text { Patient } \\
\text { initials }\end{array}$ & $\begin{array}{c}260 \mathrm{~nm} / 280 \mathrm{~nm} \\
\text { ratio }\end{array}$ & $\begin{array}{c}\text { Concentration } \\
\mu \mathrm{g} / \mathrm{ml}\end{array}$ \\
\hline M S & 1.94 & 89.23 \\
\hline S G & 1.98 & 80.41 \\
\hline M L & 1.89 & 64.73 \\
\hline $\mathrm{N} \mathrm{M}$ & 1.96 & 62.61 \\
\hline NAM & 1.94 & 46.82 \\
\hline $\mathrm{AC}$ & 1.72 & 42.19 \\
\hline $\mathrm{C} \mathrm{M}$ & 1.92 & 41.85 \\
\hline B G & 1.89 & 40.32 \\
\hline G M & 1.9 & 36.8 \\
\hline S I & 1.94 & 36.62 \\
\hline $\mathrm{C} \mathrm{P}$ & 1.95 & 31.81 \\
\hline P D & 1.88 & 31.15 \\
\hline M M & 1.91 & 31.12 \\
\hline S S P & 1.95 & 30.82 \\
\hline B I & 1.88 & 30.21 \\
\hline $\mathrm{T} \mathrm{M}$ & 1.88 & 30.08 \\
\hline P C & 1.87 & 28.18 \\
\hline C I P & 1.9 & 25.49 \\
\hline P D & 1.81 & 19.19 \\
\hline L E & 1.9 & 16.4 \\
\hline N S A & 1.85 & 16.1 \\
\hline C I & 1.85 & 15.9 \\
\hline $\mathrm{F} \mathrm{C}$ & 1.95 & 14.63 \\
\hline R R & 1.64 & 13.03 \\
\hline S B & 1.82 & 12.02 \\
\hline $\mathrm{S} \mathrm{E} \mathrm{C}$ & 1.67 & 9.28 \\
\hline G G & 1.66 & 8.7 \\
\hline D A & 1.71 & 8.37 \\
\hline G I & 1.71 & 8.04 \\
\hline A M R & 1.62 & 6.81 \\
\hline
\end{tabular}

Saliva DNA average concentration: $30.96 \mu \mathrm{g} / \mathrm{ml}$

ences between samples, and that can be a cause of major concern.

We have also checked if saliva DNA is appropriate for PCR amplification and hybridization in the current set-up of our laboratory, and the results were absolutely comparable with the 
ones obtained using PBMC DNA (Figure 1 and Figure 2).

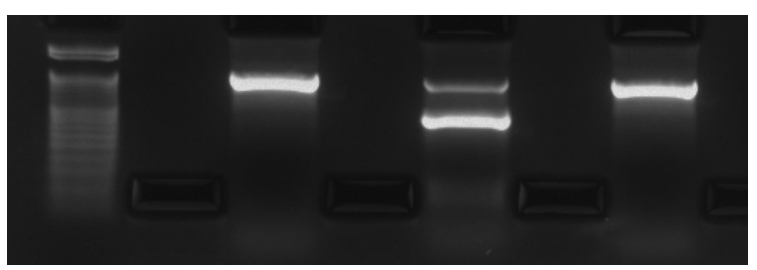

Figure 1. Amplicons generated in a PCR reaction using a BAG kit by three samples tested for HLA-B27. Sample 2 is positive, while 1 and 3 are negative.

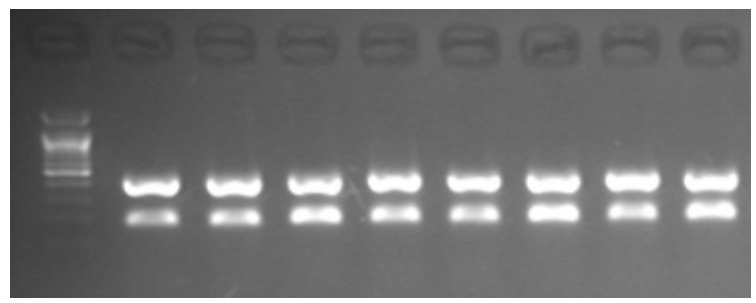

Functional Control Specificity Control Universal Control HLA-B*27 +

HLA -B*7301 +

CYP2D6 Control

CYP2D6 - WT

CYP2D $6 * 4$

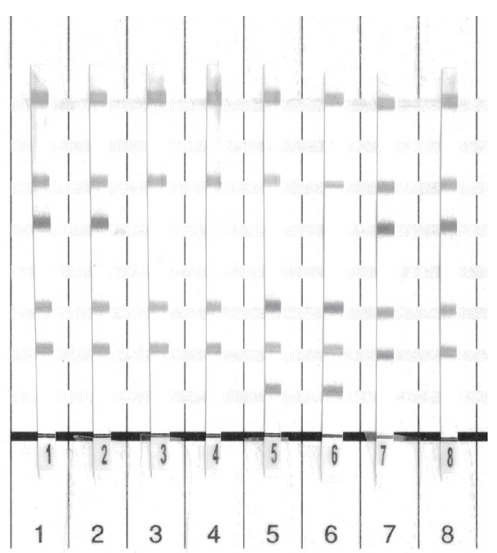

Figure 2. Saliva DNA checked in a multiplex PCR reaction followed by hybridization. A.

The amplification is initially verified by loading $4 \mu \mathrm{l}$ of the $25 \mu \mathrm{l}$ total PCR volume in a $1.5 \%$ agarose gel. B. Different hybridization patterns generated by these samples in a test targeting simultaneously for HLA-B27 and the CYP2D6*4 allele. The strips are placed in a frame supplied by the manufacturer, indicating the position of the various oligonucleotides. For example, sample \#1: HLA-B*27 positive, CYP2D6 Wild Type positive,

CYP2D6*4 negative; sample \#6: HLA-B*27 negative, CYP2D6 Wild Type positive, CYP2D6*4 positive.
We have further decided to approach saliva as an alternative for DNA extraction in the particular cases of cytopenic patients, as these patients do not present a sufficient number of white blood cells (WBC), hence they do not generate a sufficient amount of DNA, required for various molecular biology techniques currently employed by our laboratory. We have considered 9 patients with various hematological malignancies, subjected to various chemotherapy regimens.

The DNA yields obtained from blood versus saliva are presented in Table 4.

The average DNA concentration obtained from these blood samples was $10.4 \mu \mathrm{g} / \mathrm{ml}$, slightly higher than the $8.81 \mu \mathrm{g} / \mathrm{ml}$ yield obtained from saliva.

Given the rather unexpected low DNA yields generated by the saliva of these particular patients, we have raised the question if indeed

Table 4. DNA yields obtained from saliva and blood of leucopenic patients

\begin{tabular}{|c|c|c|c|c|c|}
\hline $\begin{array}{l}\text { Patient } \\
\text { initials }\end{array}$ & $\begin{array}{l}\text { WBC } \\
\text { count* }\end{array}$ & ANC & & $\begin{array}{l}260 / 280 \\
\text { nm ratio }\end{array}$ & $\begin{array}{c}\text { Concentration } \\
\mu \mathrm{g} / \mathrm{ml}\end{array}$ \\
\hline \multirow[t]{2}{*}{$\mathrm{AG}$} & \multirow[t]{2}{*}{0.24} & $0.01 * *$ & Blood & 1.72 & 10.55 \\
\hline & & $4.2 * * *$ & Saliva & 2.1 & 4.36 \\
\hline \multirow[t]{2}{*}{$\mathrm{CV}$} & \multirow[t]{2}{*}{0.3} & 0.12 & Blood & 1.73 & 10.39 \\
\hline & & 40 & Saliva & 2.28 & 14.12 \\
\hline \multirow[t]{2}{*}{$\mathrm{CP}$} & \multirow[t]{2}{*}{1.48} & 0.01 & Blood & 1.75 & 11.42 \\
\hline & & 0.7 & Saliva & 1.67 & 6.53 \\
\hline \multirow[t]{2}{*}{ FM } & \multirow[t]{2}{*}{0.45} & 0.02 & Blood & 1.74 & 11.51 \\
\hline & & 4.5 & Saliva & 2.34 & 2.8 \\
\hline \multirow[t]{2}{*}{ GGC } & \multirow[t]{2}{*}{0.56} & 0.15 & Blood & 1.66 & 13.17 \\
\hline & & 26.8 & Saliva & 2.12 & 4.48 \\
\hline \multirow[t]{2}{*}{ SM } & \multirow[t]{2}{*}{0.3} & 0 & Blood & 1.57 & 13.58 \\
\hline & & 0.1 & Saliva & 2.05 & 10.5 \\
\hline \multirow[t]{2}{*}{ VAC } & \multirow[t]{2}{*}{0.14} & 0.02 & Blood & 1.84 & 10.65 \\
\hline & & 14.3 & Saliva & 1.99 & 11.36 \\
\hline \multirow[t]{2}{*}{ GC } & \multirow[t]{2}{*}{0.71} & 0 & Blood & 1.64 & 11.56 \\
\hline & & 0 & Saliva & 1.71 & 9.27 \\
\hline \multirow[t]{2}{*}{$\mathrm{OO}$} & \multirow[t]{2}{*}{1.6} & 0.19 & Blood & 1.63 & 11.22 \\
\hline & & 11.8 & Saliva & 1.85 & 24.72 \\
\hline
\end{tabular}

$*$ Normal $=4-10 \times 10^{9} / \mathrm{L}$

$* *$ Normal $=2-8 \times 10 \% / \mathrm{L}$

$* * *$ Normal $=45-80 \%$

$\mathrm{ANC}=$ absolute neutrophil count 
the epithelial cells represent the main source of DNA, as it is currently accepted [13].

In order to verify the content of such cells in the saliva, we have initially checked saliva smears stained using May-Grünwald-Giemsa method (Figure 3).

While the May-Grünwald-Giemsa staining was able to clearly show the epithelial cells as large cells with clear cytoplasm and small nucle-
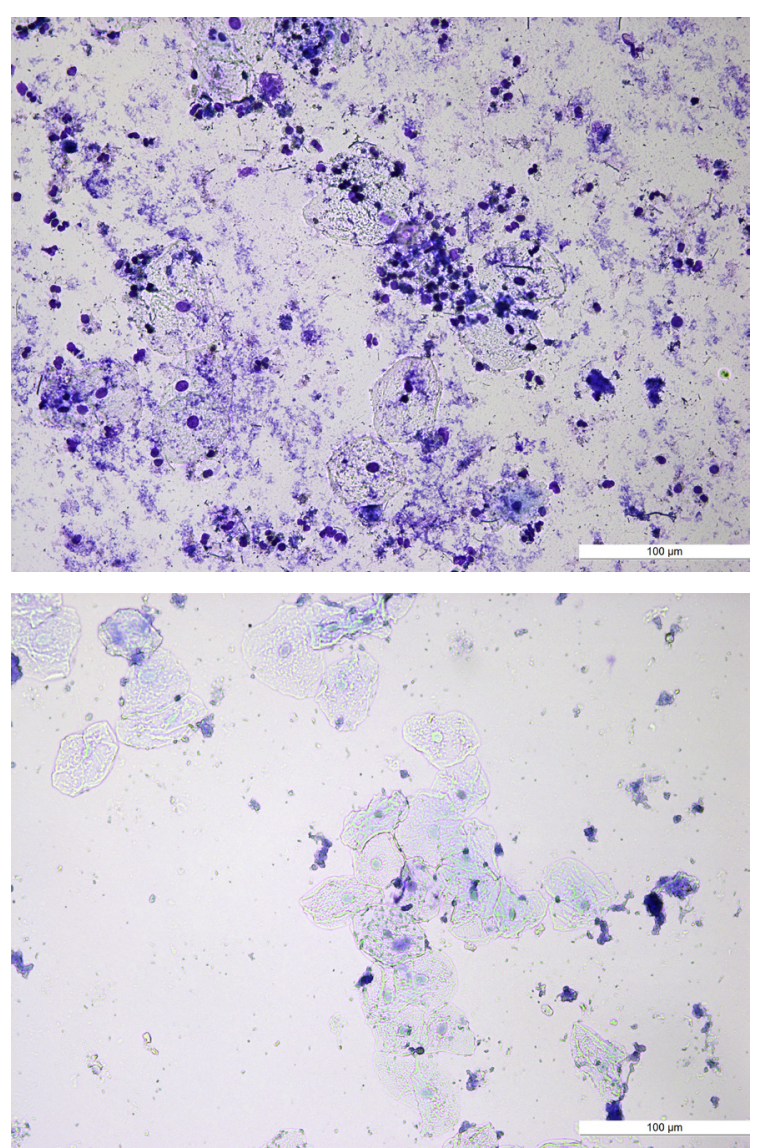

Figure 3. May-Grünwald-Giemsa staining of saliva smears: A. Saliva from a normal individual reveals epithelial cells with a large diameter and small nucleus, small cells, with a large nucleus, probably lymphocytes and cells with multilobed nuclei, probably neutrophils. B. Saliva from a patient subjected to chemotherapy shows a comparable number of epithelial cells, while the leukocytes are extremely rare (x20). us, the identification of the smaller cells present in the saliva requires specific labeling. Hence, saliva from both healthy donors and immunosuppressed patients was further analyzed by flow cytometry. We have targeted the panleukocyte CD45 molecule (Figure 4).

This analysis confirmed, as somehow expected, the low number of WBC in the saliva of the cytopenic patients, while the number of epithelial cells and epithelial debris was virtually the same.

Alternatively, the presence of leukocytes, epithelial cells and neutrophils was verified by immunocytochemistry. The labeling targeted CXCR1 and CXCR2 present on the neutrophils surface (Figure 5), epithelial cells (cytokeratin and EMA) and leukocytes (CD45) - data not shown. The epithelial cells are easily distinguishable, due to their large size. Many of the cells are broken; hence saliva smears are typically displaying much cellular debris.

\section{Discussions}

Molecular biology diagnosis is becoming increasingly used for a large array of conditions. Genomic studies have revealed gene abnormalities like mutations, deletions, rearrangements or alterations of the gene copy numbers that can pin point a certain condition. Furthermore, such genetic modifications are of maximum interest as many of them are transmitted and this leads to inherited genetic susceptibility, with a major impact in oncology if the targeted gene is a protective one [26,27]. Last but not least, therapy tends to become personalized as many new drugs are targeting particular alterations of key molecules or even entire cell signaling pathways [28]. Hence an accurate gene and molecular characterization is of great importance for both diagnosis and treatment. A key issue for such techniques is the ability to obtain a sufficient amount of good quality DNA. 

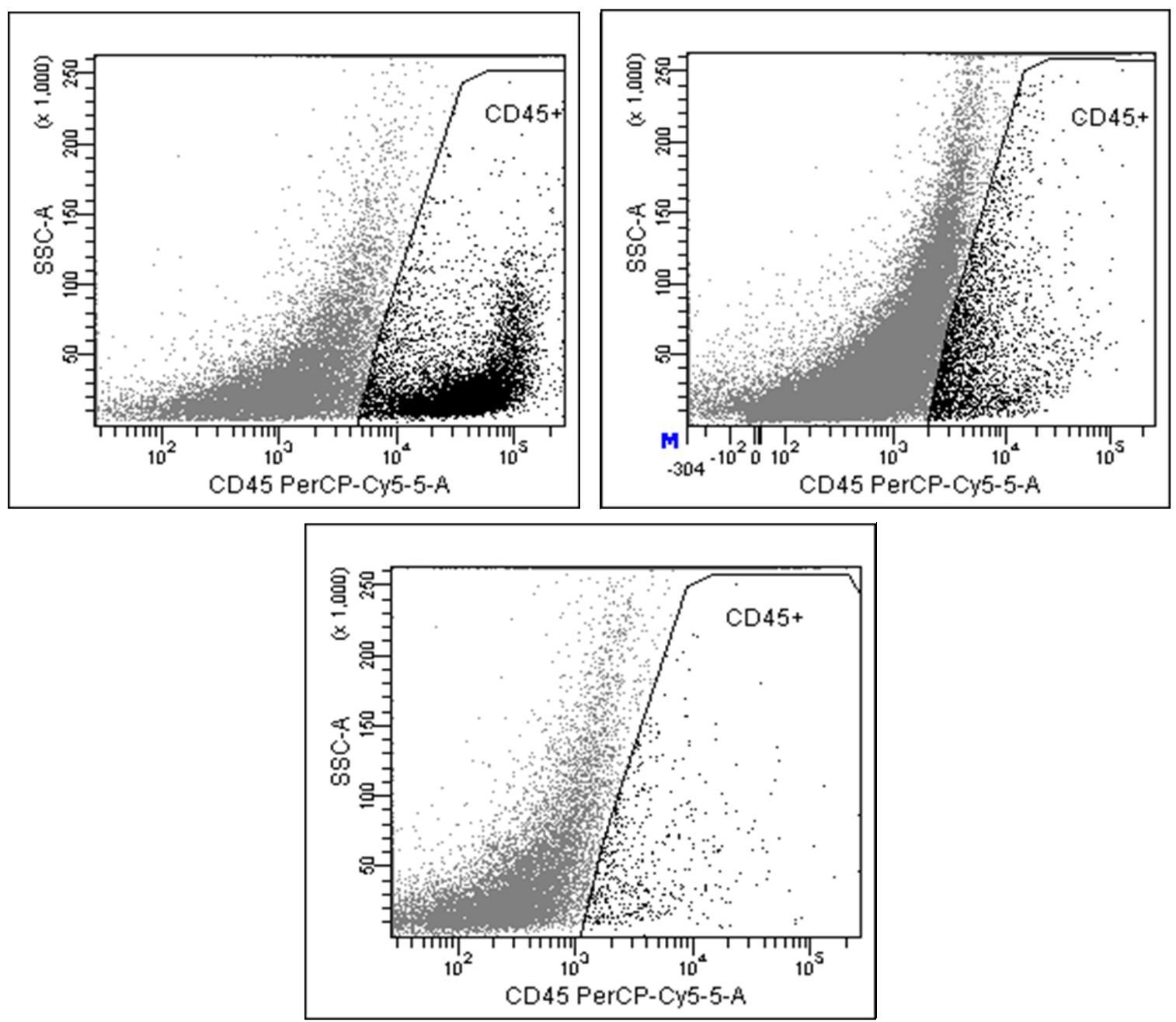

Figure 4. Flow cytometry analysis of saliva labeled for the CD45 pan-leukocyte marker. A. saliva from a normal individual, displaying 38\% CD45+ cells; B. saliva from patient AG with a concentration of 4\% CD45 + cells; C. saliva from patient FM, with a concentration of $2.7 \%$ CD $45+$ cells

The preferred source of DNA are the PBMCs (peripheral blood mononuclear cells) or, alternatively, in the case of cadaveric donor transplantation, spleen cells. As peripheral blood harvesting represents an invasive method, this raises several issues: availability of proper harvesting conditions, trained personnel, tubes with a proper anti-clotting agent, or the risk of infection. Furthermore, blood samples require refrigeration, proper tube transportation conditions and the DNA should be ideally extracted in a matter of days [29]. Largely used in forensic medicine, non-invasive alternatives are the DNA extraction from buccal swabs or brushes [30] and plucked hairs [31]. However, DNA extraction from saliva seems to be a much more advantageous method. There are several arguments in favor of this procedure. It is a very easy non-invasive harvesting method that can be performed even by the patient, and able to generate, in most cases, yields comparable to peripheral blood, as our results, obtained in different set-ups, are showing. We 


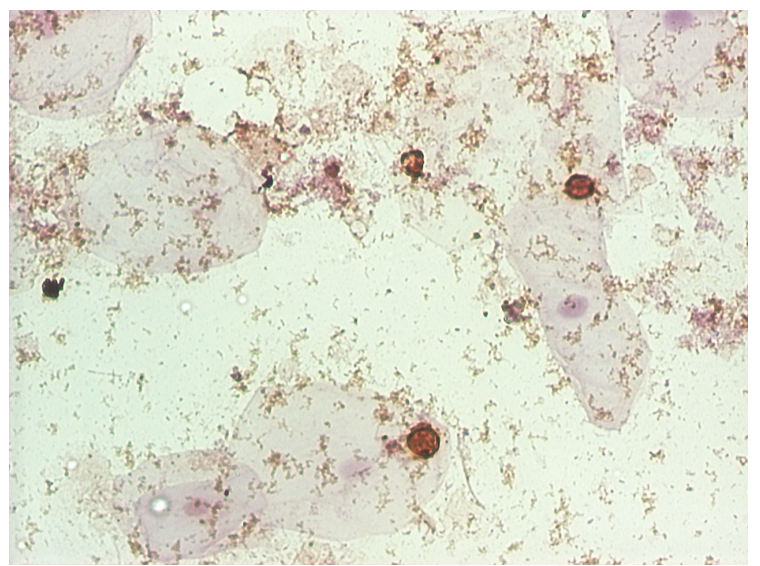

Figure 5. The cells form the saliva of a normal individual, positive for CXCR1, are, most probably, neutrophils (x20).

have used not only different saliva harvesting systems but also different DNA extraction kits, some dedicated to saliva, some dedicated to blood, and the results, as shown, were similar.

This can become thus the method of choice when the investigation targets healthy persons for various studies, patients for which veins are difficult to access, or children. The manufacturers of various saliva collecting devices put a special emphasis on the fact that saliva mixed with stabilizers proves to be a stable product $[15,16]$, which is not only easier to transport but also gains acceptability from major carriers, unlike blood or tissue samples.

It is important to note that, due to the presence of various microorganisms within the oral cavity a substantial proportion of the DNA might be non-human [8], so one would expect this approach might require specific quantitation methods [23]. On the other hand, several studies have demonstrated that not only the proportion of human DNA extracted from saliva is higher if compared to other non-invasive methods [24] but also the non-human DNA will not interfere in analyses targeting the human DNA [25]. The good quality saliva DNA, extracted using mostly commercial kits, proved to be of good qual- ity hence it could be used including for DNA sequencing, both with Sanger method [8] and NGS [11].

In order to check ourselves if the presence of non-human DNA extracted from saliva might have an impact on the outcome of various PCR amplifications and hybridization procedures we are currently performing in our laboratory, we have used this DNA for HLA genotyping. The results were fully satisfactory, and no difference could be noticed between the DNA extracted from blood or saliva.

As many molecular biology investigations are destined to oncological patients, given the impact of low cell count in the peripheral blood upon the DNA yield, we were interested to investigate if saliva can represent a viable alternative in this situation and if the exfoliated epithelial cells can represent a source of DNA. Nine such patients, with various hematological malignancies for which they were undergoing chemotherapy, were considered. A rather surprising match of the very low DNA yields extracted from both blood and saliva emerged this time as well.

It is known that in the oral cavity there is a quite remarkable turnover of epithelial cells, the layer of superficial epithelial cells being replaced roughly every 3 hours [19]. Our results demonstrated that while the number of epithelial cells remains virtually unchanged in saliva, the leukocyte number dramatically decreases in this fluid as well in immunosuppressed patients. Leaving aside the fact that in both saliva and blood extracellular (cell free) DNA is present [32], the match between blood and saliva DNA yields indicate that the most important source of DNA in the saliva samples is represented by cells travelling from the peripheral blood to the oral cavity, cells which are meant to play an important role in the protection against pathogens [33]. Hence, saliva DNA concentrations might even offer indirect information about the number of such cells reaching into the oral cavity and the 
impact upon a number of conditions that might affect the mouth.

Unfortunately, the DNA extraction from saliva proves not to be a feasible method for this category of patients, which could have benefited otherwise tremendously of an alternative method. Should saliva still be considered as a valuable sample, perhaps a different approach would prove useful, one that would rather utilize DNA extraction methods dedicated to solid tissues, as the currently dedicated available kits seem to target leukocytes.

We conclude that DNA can be easily extracted from saliva and many commercially available kits might be adapted for this purpose. As saliva harvesting is a non-invasive method, this could represent an appealing alternative for many patients and healthy persons, especially when it is necessary to recruit participants for large scale studies or family investigations and samples often need to be shipped. However, as our results are showing, it is imperative to assess the DNA concentration, as sometimes significant yield differences compared to the expected average concentration can be noticed, that will thus call for appropriate adjustments.

In the case of non-compliant persons (mostly children and old patients) or of patients with xerostomia, saliva is obviously not a good choice. Furthermore, saliva cannot represent an alternative to peripheral blood when dealing with hematologically depleted patients since saliva DNA yields will practically match the yields generated by total blood, and these patients should not be approached with this method, at least not using the currently available dedicated DNA extraction kits.

\section{Acknowledgments}

We are indebted to Camelia Mihaila for some of the DNA extractions, to Mihaela Gramescu for her help with the May-Grünwald-Giemsa stain- ing and to Roxana Avadanei for her expertise in acquiring some of the pictures.

This work was supported by the "Grigore T. Popa" Foundation for Biomedical Research.

The authors declare no conflict of interests.

\section{References}

1. Austin MA, Ordovas JM, Eckfeldt JH, Tracy R, Boerwinkle E, Lalouel JM, et al. Guidelines of the National Heart, Lung, and Blood Institute Working Group on Blood Drawing, Processing, and Storage for Genetic Studies. Am J Epidemiol. 1996;1;144(5):437-41.

2. Vaught JB. Blood collection, shipment, processing, and storage. Cancer Epidemiol Biomarkers Prev. 2006, 15(9):1582-4. DOI: 10.1158/1055-9965.EPI-06-0630

3. Beckett SM, Laughton SJ, Dalla Pozza L, McCowage GB, Marshall G, Cohn RJ, et al. Buccal Swabs and Treated Cards: Methodological Considerations for Molecular Epidemiologic Studies Examining Pediatric Populations. Am J Epidemiol. 2008; 167(10):1260-7. DOI: $10.1093 /$ aje/kwn012

4. Bennett LC, Kraemer R, Liechti-Gallati S. Buccal cell DNA analysis in premature and term neonates: screening for mutations of the complete coding region for the cystic fibrosis transmembrane conductance regulator. Eur J Pediatr. 2000; 159:99-102. DOI: 10.1007/ PL00013814

5. Gavriel G, Modi N, Stanier P, Moore GE. Neonatal buccal cell collection for DNA analysis. (Letter). Arch Dis Child Fetal Neonatal Ed. 2005; Mar;90(2):F187. DOI: 10.1136/adc.2004.062661

6. Parad RB. Buccal cell DNA mutation analysis for diagnosis of cystic fibrosis in newborns and infants inaccessible to sweat chloride measurement. Pediatrics 1998; 101:851-5. DOI: 10.1542/peds.101.5.851

7. Yoon PW, Rasmussen SA, Lynberg MC, Moore CA, Anderka M, Carmichael MS, et al. The National Birth Defects Prevention Study. Public Health Rep. 2001; 116(suppl. 1):32-40. DOI: 10.1093/phr/116.S1.32

8. Quinque D, Kittler R, Kayser M, Stoneking M, Nasidze I. Evaluation of saliva as a source of human DNA for population and association studies. Anal Biochem. 2006; 353:272-7. DOI: 10.1016/j.ab.2006.03.021

9. Rogers NL, Cole SA, Lan HC, Crossa A, Demerath EW. New saliva DNA collection method compared to buccal cell collection techniques for epidemiological studies. Am J Hum Biol. 2007; 19:319-26. DOI: 10.1002/ajhb.20586

10. Koni AC, Scott RA, Wang G, Bailey ME, Peplies J, Bammann $\mathrm{K}$, et al. DNA yield and quality of saliva samples and suitability for large-scale epidemiological studies in children. Int J Obes. 2011; 35:S113-8. DOI: 10.1038/ijo.2011.43 
11. Abraham JE, Maranian MJ, Spiteri I, Russell R, Ingle $\mathrm{S}$, Luccarini C, et al. Saliva samples are a viable alternative to blood samples as a source of DNA for high throughput genotyping. BMC Medical Genomics 2012; 5:19. DOI: 10.1186/1755-8794-5-19

12. Rylander-Rudqvist T, Håkansson N, Tybring G, Wolk A. Quality and quantity of saliva DNA obtained from the self-administrated oragene method - a pilot study on the cohort of Swedish men. Cancer Epidemiol Biomarkers Prev. 2006;15(9):1742-5. DOI: 10.1158/10559965.EPI-05-0706

13. Küchler EC, Tannure PN, Falagan-Lotsch P, Lopes TS, Granjeiro JM, Amorim LM. Buccal cells DNA extraction to obtain high quality human genomic DNA suitable for polymorphism genotyping by PCR-RFLP and Real-Time PCR. J Appl Oral Sci. 2012;20(4):46771. DOI: $10.1590 / \mathrm{S} 1678-77572012000400013$

14. Harty LC, Shields PG, Winn DM. Self-collection of oral epithelial cell DNA under instruction from epidemiologic interviewers. Am J Epidemiol. 2000; 151:199205. DOI: 10.1093/oxfordjournals.aje.a010188

15. Birnboim HC. DNA Yield with OrageneW DNA. Ottawa: DNA Genoteck, Inc.; 2004.

16. Iwasiow RM, Desbois A, Birnboim HC. Long-term stability of DNA from saliva samples stored in Oragene(R)DNA

17. Nunes AP, Oliveira IO, Santos BR, Millech C, Silva LP, González DA, et al. Quality of DNA extracted from saliva samples collected with the Oragene ${ }^{\mathrm{TM}}$ DNA self-collection kit. BMC Med Res Methodol. 2012;4(12):65. DOI: 10.1186/1471-2288-12-65

18. Looi ML, Zakaria H, Osman J, Jamal R. Quantity and quality assessment of DNA extracted from saliva and blood. Clin Lab. 2012; 58(3-4):307-12.

19. Dawes C. Estimates, from saliva analyses, of the turnover time of the oral mucosal epithelium in humans and the number of bacteria in an edentous mouth. Arch Oral Biol. 2003; 48:329-36. DOI: 10.1016/S00039969(03)00014-1

20. Moll R, Franke WW, Schiller DL, Geiger B, Krepler R. The catalog of human cytokeratins: patterns of expression in normal epithelia, tumors and cultured cells. Cell. 1982; 31:11-24. DOI: 10.1016/0092-8674(82)90400-7

21. Le Y, Zhou Y, Iribarren P, Wang J. Chemokines and chemokine receptors: their manifold roles in homeostasis and disease. Cell Mol Immunol. 2004; 1(2):95-104.

22. Holmes WE, Lee J, Kuang WJ, Rice GC, Wood WI. Structure and functional expression of a human interleukin-8 receptor. Science. 1991; 253:278-80 DOI: 10.1126/science. 1840701
23. Feigelson HS, Coetzee GA, Kolonel LN, Ross RK, Henderson BE. A polymorphism in the CYP17 gene increases the risk of breast cancer. Cancer Res. 1997 Mar;57(6):1063-5.

24. Krippl P, Langsenlehner U, Renner W, Yazdani-Biuki B, Wolf G, Wascher TC, et al. A common $936 \mathrm{C} / \mathrm{T}$ gene polymorphism of vascular endothelial growth factor is associated with decreased breast cancer risk. Int J Cancer. 2003;106(4):468-71. DOI: 10.1002/ijc.11238

25. Downward J. Targeting RAS signalling pathways in cancer therapy. Nat Rev Cancer. 2003 Jan;3(1):11-22. DOI: $10.1038 / \mathrm{nrc} 969$

26. Vaught JB. Blood collection, shipment, processing, and storage. Cancer Epidemiol Biomarkers Prev. 2006; 15(9):1582-4. DOI: 10.1158/1055-9965.EPI-06-0630

27. Richards B, Skoletsky J, Shuber AP, Balfour R, Stern RC, Dorkin HL, et al. Multiplex PCR amplification from the CFTR gene using DNA prepared from buccal brushes/swabs. Hum Mol Genet. 1993; 2:159-63. DOI: 10.1093/hmg/2.2.159

28. Vigilant L, Pennington R, Harpending H, Kocher TD, Wilson AC. Mitochondrial DNA sequences in single hairs from a southern African population. Proc Natl Acad Sci USA. 1989; 86:9350-4. DOI: 10.1073/ pnas.86.23.9350

29. García-Closas M, Moore LE, Rabkin CS, Franklin T, Struewing J, Ginzinger D, et al. Quantitation of DNA in buccal cell samples collected in epidemiological studies. Biomarkers. 2006;11(5):472-9. DOI: $10.1080 / 13547500600733820$

30. Nemoda Z, Horvat-Gordon M, Fortunato CK, Beltzer EK, Scholl JL, Granger DA. Assessing genetic polymorphisms using DNA extracted from cells present in saliva samples. BMC Med Res Methodol. 2011 Dec 19(11):170. DOI: 10.1186/1471-2288-11-170

31. Nishita DM, Jack LM, McElroy M, McClure JB, Richards J, Swan GE, et al. Clinical trial participant characteristics and saliva and DNA metrics. BMC Med Res Methodol. 2009;29(9):71. DOI: 10.1186/14712288-9-71

32. Vandewoestyne M, Van Hoofstat D, Franssen A, Van Nieuwerburgh F, Deforce D. Presence and potential of cell free DNA in different types of forensic samples. Forensic Sci Int Genet. 2013;7(2):316-20. DOI: 10.1016/j.fsigen.2012.12.005

33. Challacombe SJ, Shirlaw PJ. Immunology of Diseases of the Oral Cavity. In: Mestecky J, Lamm ME, Strober W, Bienenstock J, McGhee JR, Mayer L, editors. Mucosal Immunology 3rd ed. London Elsevier Academic Press 2005: 1517-1546. DOI: 10.1016/b978012491543-5/50093-0 
